\title{
ANNUAL SUBSISTENCE CYCLE OF THE CHEPANGS IN MID-HILLS OF NEPAL: AN INTEGRATION OF FARMING AND GATHERING
}

\section{Keshav Lall MAHARJAN Luni PIYA Niraj Prakash JOSHI}

\section{INTRODUCTION}

Along the Mahabharat range, in the remote and steep terrains bounded to the South of Trishuli River (Prithvi Highway), North and West of the Rapti River (East-West Highway and Tribhuwan Highway respectively), and East of the Narayani River (Mugling-Narayangarh Highway), lies the traditional area of the Chepangs: one of the indigenous nationalities ${ }^{1}$ of Nepal. In the administrative division of the country, their traditional area falls in the West of Makawanpur district, Northeast of Chitwan district, and South of Dhading district. There are also quite significant population of Chepangs to the north of Trishuli River in the Southeast of Gorkha District, believed to have migrated from their traditional region (Rai, 1985). Although major highways of the country surround their traditional area, a large part of Chepang settlements are still untouched by motorable roads and feeder roads joining their settlements to the highways are almost absent. According to the population census 2001, the total Chepang population is 52,237 constituting $0.23 \%$ of the total population of Nepal (CBS, 2003). Of the total Chepang population, 40.67\% lives in Chitwan district, 29.39\% in Makwanpur district, 20.82\% in Dhading district, and 5.25\% in Gorkha district; the four districts thus form the home to more than $95 \%$ of the total Chepang population (CBS, 2008). Majority of the Chepangs live in the hilly Village Development Committees (VDCs) of these four districts namely Kabilas, Chandibhanjyang, Dahakhani, Darechowk, Kaule, Shaktikhor, Siddhi, Korak, Lothar, and Piple VDCs in Chitwan district; Manahari, Raksirang, Kankada, Khairang, Dadakharka, Bharta, Kalikataar, and Sarikhet-Palase VDCs in Makwanpur district; Jogimara, Gajuri, Mahadevsthan, Pida, Dhusa, and Benighat VDCs in Dhading district; and Taklung, Makaising, Tanlichowk, Bhumlichowk, 
and Ghyalchowk VDCs in Gorkha district. Brian Hodgson was the first scholar to write about the Chepangs in 1848. In the last three decades, many anthropological and sociological studies have been done on the Chepangs (Riboli, 2000; Gurung 1995, 1994b, 1994a; Neis, 1989; Rai, 1985). Few quantitative studies have been done on the socio-economic aspects of the Chepangs (FORWARD, 2001a, 2001b; Gribnau et al., 1997).

The Chepangs were named as Praja (King's Subjects) by the late king Birendra during his tour to the Central Nepal in 1977. Thereafter, the Chepangs preferred to be called Praja as they regarded their ethnic name as derogatory, thinking it was often used by neighbouring Bahuns to tease them (Rai, 1985). However, over the last ten years especially after the formation of Nepal Chepang Association (NCA) in 1998 by few young and active Chepangs in Kathmandu, the younger generations in particular have steadily rejected the Praja name, which came to symbolize subservience (SNV, 2008; Bhattarai, 1999) and rather opt to be called Chepang, which maintains their ethnic identity and dignity. In 2004, the then His Majesty's Government of Nepal, agreed to apply the terms 'Chepang' instead of 'Praja' for citizenship certificates.

As an indigenous group, Chepangs have their own language Chepang bhasa, which is of Tibeto-Burman origin. They also have their own spiritual belief. According to the NCA, Chepangs are Prakriti pujak (worshippers of nature). The Chepangs worship all the elements of nature like trees, river, stones, land, and so on. However, in the past, a dominant and persistent Hindu ethos attempted to define their traditional beliefs as insignificant and counted them under Hindu religion (SNV, 2008). Also, when they were issued citizenship certificates, their religion was stated as Hindu without allowing them to correct it. After 1981, a significant population of Chepangs has converted to Christianity, which was first of all introduced by a linguist from New Zealand in 1981 in Maisirang village in Kankada VDC of Makawanpur, where he stayed 5 years to learn Chepang language (Bhattarai, 2004, 1999). Christianity among Chepangs is often viewed from two aspects. The Christian missionaries have successfully blended themselves within the Chepangs society by learning their language and living together in their houses. They 
have motivated the Chepangs to quit irrational drinking and smoking habits. Besides, the Christian missionaries have also provided various opportunities for the education of the Chepang children, and health facilities to the community. As a result, many Chepangs have followed Christianity. However, the Chepang activists and members of NCA see this as a major challenge to preserve their traditional knowledge, especially the use of medicinal plants in local healing (Personal Communication with Yaman Chepang, Central Member of NCA, 27 $7^{\text {th }}$ February 2009). Due to the heavy influence of Hindu culture, they celebrate many Hindu festivals like Dashain, Tihar, Maghe Sankranti, and Sawane Sankranti. However, they also have their own festivals like Nwagi or Chhonam (celebration of new harvest), Kulayan puja (celebration of the clan), Aitabare puja (celebration performed to prevent natural disasters), and Bhume puja (Celebration of the mother earth). Among them Nwagi is the most important festival, which is basically the festival of new harvest. The NCA has declared Nwagi as the major festival of Chepangs. During this occasion, the harvest is offered to the dead ancestors of the clan. The Chepangs do not eat new harvest of rice, citrus fruits, and Colocasia until Nwagi is celebrated. The religious beliefs and practices of Chepang community have been studied in detail by Gurung $(1995,1994 b)$. The Chepangs are believers of Shamanism as well. The Chepang shaman called Pande (or Jhakri) plays an important role in a number of religious and social activities of the Chepangs, such as the name-giving ceremony for a newborn baby, worship of a clan deity, funeral, and Nwagi. Pande is also a curer of illness. For all these purposes, the Pande invokes and propitiates various deities and the ancestors. During these occasions, Pande beats a one-sided drum with a crooked stick or recite some magical spells on some occasions. A new Pande can be trained by another expert or can be selected by the gods, in which case it is believed that the Pande receives mantra (spell) in his dreams. Riboli (2000) has conducted an in-depth study of Shamanism among the Chepangs.

Chepangs are categorized as highly marginalized ${ }^{2}$ indigenous nationalities of Nepal. Poverty, illiteracy, lack of food self-sufficiency and food security, and lack of resource ownership are some of the common characteristics of the Chepangs (Piya et al., 2011a, 2011b). Ignorant of administrative requirements and official procedures many 
Annual subsisteence...... Piya, Maharjan, Joshi

Chepangs are still devoid of citizenship certificates. Chepangs dwell in marginal land, usually in the steep slopes. Chepangs have been the owners of their land since time immemorial. However, due to their practice of khoriya cultivation in olden days in place of organized agricultural methods, they do not have legal ownerships of lands they have been using. Even in cases where they have official title to their private lands, the little land that they have is poor and infertile. Farming is often practiced in marginal land, and is not enough to provide for them for the whole year. During the lean period, Chepangs depend on forests to gather wild edibles like tubers, yams, and fruits (Piya et al., 2011a; Bastakoti and Kattel, 2008; Aryal et al., 2009; Gribnau et al., 1997; Gurung, 1995). However, control over and access to forest resources has been severely restricted due to unfavourable state policies, which in turn threaten their traditional livelihoods (Upreti and Adhikari, 2006).

Often described as guardians of the forest, Chepangs are believed to be until the last 100-150 years ago a semi-nomadic hunter / gatherer group ranging the forests of Nepal as described by Brian Hodgson in his 1848 article 'On the Chepang and Kusunda Tribes of Nepal' to be "living entirely upon wild fruit and the produce of the chase" (Hodgson, 1874; p. 45). It is supposed that agriculture is comparatively a newer phenomenon for them (Bhattarai et al., 2003; Gribnau et al., 1997; Gurung, 1995). Nearly a century after Hodgson, a comprehensive study about Chepangs by Rai (1985) reported that though Chepangs still practiced a good deal of hunting and gathering, agriculture formed the mainstay of their livelihood, and they practiced khoriya or shifting cultivation. Under this system, a patch of land was cleared in the forest and cultivated for three continuous years before the soil became exhausted. It was then left fallow for seven years; meanwhile they cleared and cultivated other patches of land. However, their access to forest was severely restricted due to the introduction of new government policies, most notably the enactment of Private Forest Nationalization Act in 1957, under which all the forests that had been used from the past under the traditional rights were included under the government ownership. This put a restriction in the hunting and gathering activities, thereby negatively affecting the traditional system of the Chepang livelihoods. Chepangs had no legal ownership 
of land where they practiced khoriya, and most of them remained as uncultivated patches within the forest area, which was now under the government ownership. Cadastral survey conducted in the Chepang area in early 1970s only registered lands that were permanently cultivated as private properties, thereby failing to recognize khoriya patches as land suitable for registration. Enactment of Forest Act 1993 further strengthened the government ownership of forests, and introduction of community and leasehold forestry banned all the hunting and cultivation activities within the forest area. Restrictions on hunting, gathering, and clearing of forest patches for khoriya cultivation led to the transition of their livelihood to sedentary agriculture. They mostly grow maize, millet, buckwheat, black gram, soybean, and mustard in upland and khoriya; they also cultivate rice, wheat, and vegetables if they own lowland or irrigated upland. However, only a small percentage of Chepang households are fully food self-sufficient. Though agriculture forms the mainstay of their livelihood, Chepangs still depend upon forest resources to a large extent and the contribution of wild and uncultivated edible plants play an important role in their subsistence economy. In the following sections, this paper will discuss in detail how the Chepangs combine farming and gathering to sustain their subsistence livelihoods. Besides gathering, Chepangs also depend upon livestock, wage laboring, collection and sale of NTFPs, skilled and salaried jobs, handicrafts, and remittance for cash income. Most of their cash income is spent in procuring food. During the time of their food deficit, the Chepangs have to depend on the other communities like Bahuns, Chhetris, and Newars for loan, which they pay back by selling goats, black gram, soybean, or other forest products like NTFPs, and honey (FORWARD, 2001b; Gribanu et al., 1997).

\section{THE STUDY SETTINGS}

The study was conducted in Shaktikhor VDC in Chitwan district and Handikhola VDC in Makawanpur district (Figure 2 and 3). In Shaktikhor VDC, there are approximately 400 Chepang households with a total Chepang population of 2,575 , which is $34.7 \%$ of total population in the VDC. Chepangs are the largest population among the ethnic groups in Shaktikhor VDC. In Handikhola VDC, there are approximately 230 Chepang households with total Chepang population of 1,420, which 
Annual subsisteence...... Piya, Maharjan, Joshi

is $7.3 \%$ of the total population in the VDC. Chepangs form the fourth largest population of the ethnic groups in Handikhola VDC. Elevation of Shaktikhor varies from approximately 275 - 1400 meters above sea level (masl) while that of Handikhola varied from 315 - 720 masl (NGIIP, 2006). The Chepang settlements in both these VDCs are in close proximity to forests. The Chepang settlements are situated up on hillsides and the households are scattered. The topography of the settlements is very rugged, and from a distance the settlements tend to be hidden by ridges and jungles. The settlements are connected by narrow trails running parallel to hillside ridges. During rainy season, the trails are covered with undergrowth and leeches are prevalent. Also, falling stones and landslides are a danger. During monsoon, the rivers that run along the ridges are flooded making it difficult to move across the settlements.

Shaktikhor VDC is linked to the East-West Highway by an all season earthen road but only up to the foothills of the VDC, where the main bazaar is located 13 kilometers northeast of Tandi Bazaar in the EastWest Highway. Other Chepang VDCs surrounding Shaktikhor (i.e. Siddhi, Korak, Kaule and Lothar VDCs) are not connected by motorable roads. Thus Shaktikhor is the main market center for the inhabitants of the adjoining hilly VDCs. From Shaktikhor bazaar, one has to climb steep winding paths uphill to access the Chepang settlements. Most of the Chepang settlements in Shaktikhor are situated at an altitude of 800 to 1400 masl. These settlements are sparse, and are connected by narrow foot-trails that run all over the hillsides.

Handikhola VDC, on the other hand is separated from the East-West Highway by the Rapti River. Because of the absence of bridge over Rapti, transportation facilities to Handikhola VDC are available only during winter. Even during winter, transportation touches only a small portion of Handikhola VDC, thus a larger part of the VDC is untouched by transportation all the year round. Futhermore, Handikhola VDC is traversed by many rivulets, which are very difficult to cross through during the rainy season. Chepang settlements in Handikhola are situated on the ridges, and each ridge is separated from the other by a rivulet that flow in the grove between the ridges so that in order to go from one settlement to another, one has to climb down the grove, cross 
the rivulet, and again climb up the ridge. During monsoon, the rivulets are flooded and the ridges are very slippery, so that movements across the settlements become very difficult. The nearest market located in the East-West Highway is Sannantaar, which can be reached only after crossing the Rapti River. During monsoon, when the level of water in Rapti rises, Handikhola VDC becomes disconnected from the Highway.

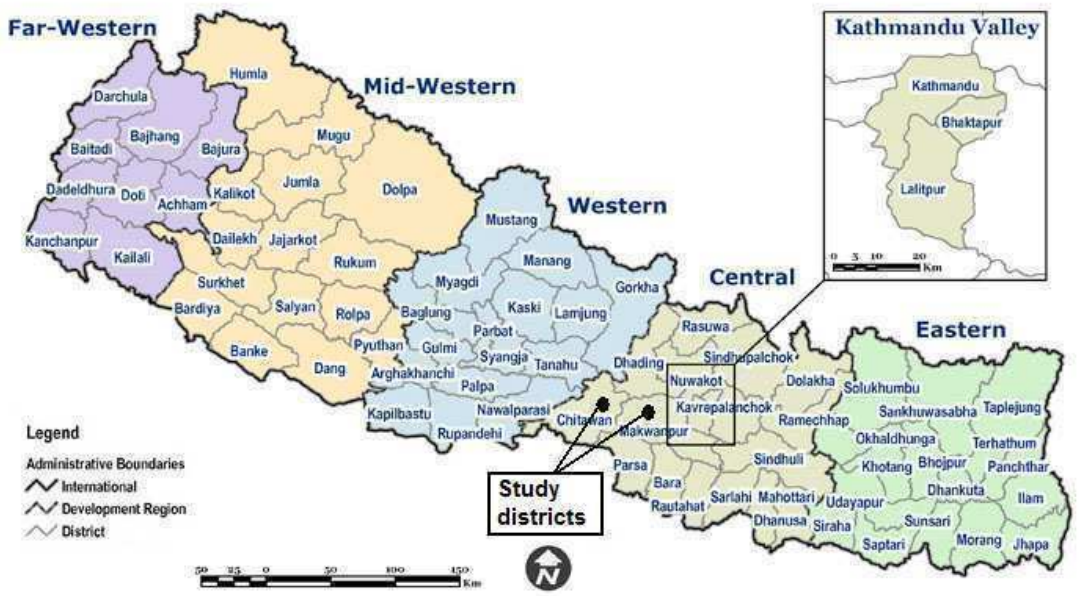

Figure 1. Map of Nepal showing Chitwan and Makawanpur districts

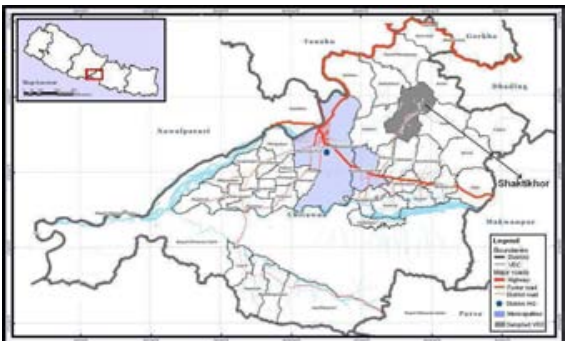

Figure 2. Map of Chitwan district showing Shaktikhor VDC

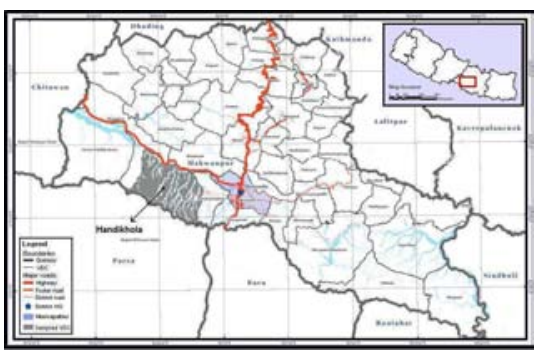

Figure 3. Map of Makawanpur district showing Handikhola VDC

Data on household characteristics were collected by a systematic household survey. The household survey was used to generate quantitative data in a structured form that could serve descriptive analysis. A semi-structured interview schedule was prepared containing both closed and open-ended questions. Questions were designed to obtain information on the demographic structure; socio-economic 
Annual subsisteence...... Piya, Maharjan, Joshi

characteristics like education, occupation, landholdings, and livelihood activities; and forest resource dependency for various purposes like food, fodder, litter, timber, fuel wood, housing, and so on. Before the selection of sample households, a reconnaissance survey of the study VDC was carried out to get general information about the location of settlements, availability of lodging facilities, and walking distances. A total of 120 households, 60 households from each VDC were selected as the sampling units. It accounts for $15 \%$ of total Chepang households in Shaktikhor VDC of Chitwan district, while it is $26.1 \%$ of total Chepang households in Handikhola VDC of Makawanpur district. The households were selected randomly taking into considerations factors like accessibility, security, and within the walking distances from the place of home-stay.

Five enumerators were hired for assisting the researchers in the household survey. The aim of the survey, and the purpose and use of the questionnaire were explained to the enumerators elaborately during the orientation. The researcher and the enumerators visited each of the selected households and all interviews took place on the selected household's premises. Each informant was first made aware of the objectives of the study. Probing was also done to further clarify the responses and triangulate the information given by the respondents. The time required to administer one questionnaire was nearly 2 hours. Household survey in Shaktikhor VDC was conducted in Chepang households lying at a walking distance of 30 minutes to 5 hours uphill after getting off the bus at the foothills of the VDC. The households covered lie in ward number 2, 3, 4, and 5 of Shaktikhor VDC. Ward number 2 and 5 lie nearer to the foothills while 3 and 4 lie farther away and is accessed only after a tough uphill climb. The household survey in Shaktikhor covered the Chepang settlements of Chinaraang, Kolar, Sherwas, Saaldanda, Kuwapaani, Samfaryang, Supaar, Gadhigaun, Darbetaar, and Bhyuraan. The household survey was conducted during the rainy season. Thus, Handikhola VDC was accessible only on foot. The study covered ward number 7 of Handikhola VDC, and covered the Chepangs settlements of Taarubans, Dolbaari, Lampakha, Chisapaani, Masiney, Narsingh Taandi Tol, and Barra Tandi. The households covered in Handikhola VDC lie at a walking distance of 2 to 6 hours from the East-West highway. Household survey was 
conducted in August - September 2008 and follow-up field visits were done in February - March 2009 and February - March 2010.

Information was also collected through key informants' interview, group discussions, and researcher's observations. Focal group discussions with Chepang community were mostly carried out at local gathering places. Information on annual pattern of food gathering from the forests, locally available fodder species, plants used for domestic purposes like housing/ roofing, and plants of cultural / ritual importance were gathered from group discussions. These were supplemented with participant observations and informal discussions with local residents. To supplement the data from primary sources, various secondary sources were also reviewed.

\section{FARMING}

\section{LANDHOLDING AND CROPS GROWN}

Landholding among the Chepangs can be classified into three categories: Khet (irrigated land suitable for paddy transplantation), Bari (terraced upland, usually unirrigated), and Khoriya (sloppy unirrigated upland without terraces). Khet is the most fertile category of land, usually situated in the foothills nearby the streams. Bari and Khoriya are very stony, sloppy, and lacks irrigation facilities due to which they are less productive. Khet is considered an important asset for the households as it has the highest productivity, and three consecutive crops of Paddy (Oryza sativa), wheat (Triticum vulgare), and maize (Zea mays) can be cultivated thereby having higher contributions to the food self-sufficiency of the household. However, owing to the topography of the settlements, very few households own Khet, which is usually situated at lower elevations far from the houses. In this study, it was found that only around $37 \%$ of the sample households owned Khet, average area per household being 0.28 hectares (Table 1). Most of the households (more than 90\%) owned Bari, the average area per household being 0.47 hectares, while around $43 \%$ households owned Khoriya, the average area being 0.46 hectares. The findings are similar to the study by Gribnau et al. (1997) who reports that $21 \%$ of Chepang HHs in four VDCs of Chitwan district owned khet, 98\% owned bari, and 95\% owned khoriya. Area per household is significantly higher in Shaktikhor than in Handikhola for all categories of land. Average 
landholding is significantly higher in Shaktikhor (1.15 ha) compared to Handikhola (0.33 ha). The average landholding for Shaktikhor is higher than the national average for hills, which is 0.66 ha per household according to the 2001 census (CBS, 2006). The figure for Handikhola is much lower than the national average for hills.

Table 1. Average Landholding of the Sample Households by Land Category (in ha)

\begin{tabular}{|l|c|c|c|c|c|c|}
\hline \multirow{2}{*}{$\begin{array}{c}\text { Land } \\
\text { Category }\end{array}$} & \multicolumn{2}{|c|}{ Shaktikhor $(\mathrm{n}=60)$} & \multicolumn{2}{c|}{ Handikhola $(\mathrm{n}=60)$} & \multicolumn{2}{c|}{ Overall $(\mathrm{n}=120)$} \\
\cline { 2 - 7 } & No. of HHs & Area/HH & No. of HHs & Area/HH & No. of HHs & Area/HH \\
\hline Khet & $29(48.3)$ & 0.32 & $15(25.0)$ & 0.19 & $44(36.7)$ & 0.28 \\
\hline Bari & $54(90.0)$ & 0.71 & $58(96.7)$ & 0.24 & $112(93.3)$ & 0.47 \\
\hline Khoriya & $35(58.3)$ & 0.62 & $17(28.3)$ & 0.15 & $52(43.3)$ & 0.46 \\
\hline $\begin{array}{c}\text { Total } \\
\text { Landholding }\end{array}$ & $60(100.0)$ & 1.15 & $59(98.3)$ & 0.33 & $119(99.2)$ & 0.74 \\
\hline
\end{tabular}

Source: Field survey, 2008

Note: Figures in parenthesis indicate percentage

Those households which have no Khet rely mostly on Bari and Khoriya for grain production. Maize, and millet (Eleusine corocana), the two most important staple crops for the Chepangs, are grown in Bari and Khoriya. Besides these, Chepangs also cultivate buckwheat (Fagopyrum esculentum), and mustard (Brassica campestris var. Toria) in Bari, but in lesser quantities. Legumes like soybean (Glycine max), and blackgram (Vigna mungo) are planted along with paddy on the bunds of Khet, while cowpea (makai bodi ${ }^{3}$ ) (Vigna spp) is mixed-cropped with maize. Other legumes like a different variety of cowpea (kattike bodit) (Vigna spp), masyang (Phaseolus aconitifolius), and horsegram (Dolichos biflorus) are usually cultivated in Khoriya. Cereals like sama, kaguno (Setaria italica), and junelo (Sorghum vulgare) which the Chepangs used to cultivate till some 35 years ago (see Rai, 1985), are no more cultivated. Chepang households maintain a small kitchen garden in their courtyard or in the field nearby their houses, where they plant limited varieties of vegetables and spice crops. Chepangs commonly plant broad leaf mustard (Brassica juncea), pumpkin (Cucurbita maxima), radish (Raphanus sativus), gourds [sponge gourd (Luffa cylindrica), snake gourd (Trichosanthes anguina), 
bottle gourd (Lageenaria siceraria), and bitter gourd (Momordica charantia)], cucumber (Cucumis sativus), chayote (Sechium edule), and colocasia (Colocasia antiquorum). Other less commonly planted vegetables include barela (Momordica balsamina), brinjal (Solanum melongena), beans [snap bean (Phaseolus lunatus), four season bean, winter bean (Dolichos lablab)], okra (Abelmoschus esculentus), tomato (Lycopersicon esculentum), onion (Allium cepa), potato (Solanum tuberosum), cauliflower (Brassica oleracea var. bortrytis) and cabbage (Brassica oleracea var. capitata); these vegetables are still very new to the Chepangs mostly introduced by the development agencies working in the area and are grown only by few households owning Khet or irrigated Bari. The most commonly planted spice crop is chilly (Capsicum annum) besides which they also plant garlic (Allium sativum), ginger (Zingiber officinale), and turmeric (Curcuma domestica). Chepangs cultivate very limited quantities of vegetables and spice crops due to the lack of irrigation facilities. Also, openly reared chicken and pigs are a problem as they run around the homestead in search of food, and destroy young vegetable seedlings in the kitchen garden.

\section{THE ANNUAL CROPPING CYCLE}

Maize and millet, the two important staple crops for the Chepangs are cultivated by all the households. After the harvest of winter crops, the field is ploughed and manured for the cultivation of maize. During Falgun - Chaitra (for conversion of Nepali months into English calendar, see Annex 1), after the intermittent spring rains, maize seed is broadcasted. If the onset of spring rain is late, broadcasting of maize seeds may be delayed until Baisakh. Immature cobs are consumed from Asadh, the mature cobs are harvested from late Shrawan till Bhadra depending on the sowing time. Cowpea (makai Bodi) is sown together with maize seeds. Green cowpea pods are eaten as vegetables during Jestha - Asadh, while mature seeds are harvested together with maize in Shrawan-Bhadra, and used as daal.

After maize, millet is transplanted in Bari and Khoriya. Millet is sown 
in seed-beds on dry land in Asadh and transplanted about a month later. If the previous crop of maize is sown late, then this disturbs the transplantation of millet seedling. Under such circumstances, seedling transplantation of millet is delayed until Bhadra. Some households transplant the seedling while the maize is still standing in the field. Many Chepang households simply broadcast the millet seedlings on ploughed fields. Millet is harvested from late Kartik till early Poush. Besides millet, Chepangs also sow legumes like cowpea (Kattike Bodi), masyang, and horsegram after maize harvest. These legumes are usually sown in Khoriya. Green pods of cowpea is sometimes consumed as fresh vegetables, however these legumes are mostly grown for the purpose of pulses. Mature legume seeds are harvested in Mangsir - Poush. After the harvest of millet/legumes, the land remains fallow for 2-3 months. In Falgun, before the onset of spring rains, the crops stubbles are burned and the land is ploughed to prepare for sowing maize. In Asoj-Kartik, Buckwheat in sown in Bari in higher altitudes, where millet is not sown. Because Handikhola VDC is situated in comparatively lower altitude, buckwheat is not sown there. Chepangs in Shaktikhor barter buckwheat for unprocessed salt (dheeka noon ${ }^{5}$ ) with tradesmen who visit the villages from plain areas. Another winter crop less commonly cultivated is mustard, which is also sown in Bari where millet is not cultivated. Buckwheat is harvested during Poush Magh and mustard is harvested during Magh - Falgun.

The few households who own Khet plant paddy after harvesting maize. As irrigation is available in Khet, maize is usually planted early in Falgun, and is thus harvested earlier in late Asadh till early Shrawan. Paddy seedling sown in seedbeds in Jestha is ready to be transplanted by the time maize is harvested in Asadh - Shrawan. Land is thoroughly ploughed, puddled, and leveled before paddy seedlings are transplanted. Paddy is ready for harvesting in Kartik - Mangsir. Soybean and Blackgram are planted in the bunds of Khet during rice transplantation and mature seeds are harvested in Mangsir - Poush. Soybean and blackgram are usually sold in the road-head markets for cash income, or to pay back the loans taken 
from road-head moneylenders. After paddy harvest in Kartik Mangsir, wheat seeds are sown in Khet. Some households may also sow wheat in Bari after millet is harvested. However, wheat is not commonly sown in Bari as it needs heavy manuring, whereas Baris are manured only once prior to maize seed broadcasting. Wheat can be harvested from late Falgun till Chaitra. The annual cropping cycles followed by the Chepangs can be summarized as follows:

\begin{tabular}{|l|l|l|}
\hline \multicolumn{1}{|c|}{ Bari } & \multicolumn{1}{|c|}{ Khoriya } & \multicolumn{1}{c|}{ Khet } \\
\hline $\begin{array}{l}\text { Maize - Millet / Buckwheat } \\
\text { / Mustard }\end{array}$ & $\begin{array}{l}\text { Maize }- \text { Millet / } \\
\text { Legumes (Cowpea/ } \\
\text { Masyang/Horsegram) }\end{array}$ & $\begin{array}{l}\text { Maize - Paddy - } \\
\text { Wheat }\end{array}$ \\
\hline $\begin{array}{l}\text { Note: Maize is mixed cropped with Cowpea (Makai Bodi). } \\
\text { Paddy is intercropped with Soybean and Blackgram. } \\
\text { Buckwheat is not cultivated in Handikhola. }\end{array}$ \\
\hline
\end{tabular}

Chepangs don't give much emphasis on the cultivation of vegetables and spice crops. Of the few plants sown in the kitchen garden, fewer survive due to destruction by chickens, pigs, drought, disease, and pest infestation. Among the spice crops, chilly is an indispensable part of the Chepang diet. They plant chilly seedlings during summer months, which can be harvested from Jestha till Poush depending on the planting date. They dry the surplus for future use, and buy the insufficient amount when they visit the roadside markets. Most of the vegetables grown by Chepangs are summer vegetables, pumpkin being the most important one, as the young shoot can be used as green vegetables, the fruits can also be eaten as vegetables, and surplus mature ones can be stored for future use. The seeds of pumpkin are sown from Falgun to Baisakh along the bunds of the fields when maize is sown. Young shoots can be consumed from Chaitra till Bhadra. Young pumpkin fruits can be consumed from Asadh till Bhadra, while mature fruits are harvested in Asoj and stored for future use. Gourds (sponge gourd, snake gourd, bottle gourd, and bitter gourd) are planted from Falgun till Baisakh and are consumed throughout summer from Jestha till Asoj. Chepangs also plant cucumber during Falgun - Chaitra which can be eaten from Asadh to Bhadra. Indigenous varieties of cucumber can be left to mature in the plant, and can be stored for few months. However, these days, indigenous varieties of cucumber are becoming rare, mostly replaced by hybrid seeds. Increasing disease and pest infestation has been reported in the cucurbitaceous vegetables (pumpkin, gourds, and cucumber) after the introduction of hybrid seeds. Colocasia is planted 
Annual subsisteence...... Piya, Maharjan, Joshi

during Falgun - Chaitra, and leaves are used as green vegetables during Shrawan - Bhadra, while the tubers are dug from Mangsir to Magh. During the winter, the only green vegetables planted by Chepangs are broad-leaved mustard, and radish. Broad leaved mustard are planted during Bhadra - Asoj, and consumed from Asoj throughout the winter till Magh. Surplus leaves are fermented to make gundruk and stored to be used as vegetables for dry months. Radish is planted from Shrawan to Kartik and is consumed from Asoj to Poush. Chayote, a perennial climber, is another common vegetable among the Chepangs. Fruits of Chayote can be harvested from Asoj till Poush. Chayote can also be bartered with unhusked paddy. The cropping calendar for the major crops grown by the Chepangs is given in Annex 2 .

\section{LIVESTOCKS}

Owing to the difficult topography, goat is the most important livestock for the Chepangs as the goats can graze in any difficult topography. Trade of goat is important source of cash income in Shaktikhor and the surrounding VDCs. As depicted in Table 2, most households in Shaktikhor rear goats and the average number of goats per household is much higher in Shaktikhor compared to Handikhola. Gribnau et al. (1997) also reported that 33\% of cash income is from goats for Chepangs of Shaktikhor, Siddhi, Kaule, and Korak VDCs in Chitwan districts. Market for goat in Shaktikhor is very well developed and buyers from many adjoining districts and major market centers like Narayanghat, Hetauda, and Mugling come to the village to buy goats. Income from goats is used to buy insufficient grains, other domestic consumables like kerosense, salt, clothes, and to repay the loans taken from moneylenders during food shortages and emergencies.

Table 2. Average Number of Livestock Holding by Different Livestock Categories

\begin{tabular}{|l|c|c|c|c|c|c|}
\hline \multirow{2}{*}{ Livestock } & \multicolumn{2}{|c|}{ Shaktikhor $(\mathrm{n}=60)$} & \multicolumn{2}{c|}{ Handikhola $(\mathrm{n}=60)$} & \multicolumn{2}{c|}{ Overall (n=120) } \\
\cline { 2 - 7 } & $\begin{array}{c}\text { No. of } \\
\text { HHs }\end{array}$ & $\begin{array}{c}\text { Mean No. } \\
\text { owned }\end{array}$ & $\begin{array}{c}\text { No. of } \\
\text { HHs }\end{array}$ & $\begin{array}{c}\text { Mean No. } \\
\text { owned }\end{array}$ & No. of HHs & $\begin{array}{c}\text { Mean No. } \\
\text { owned }\end{array}$ \\
\hline Goat & $57(95.0)$ & 13.2 & $49(81.7)$ & 5.4 & $106(88.3)$ & 9.7 \\
\hline Cow/Bullock & $56(93.3)$ & 5.7 & $51(85.0)$ & 3.6 & $107(89.2)$ & 4.7 \\
\hline Buffalo & $10(16.7)$ & 3.1 & $23(38.3)$ & 1.4 & $33(27.5)$ & 1.9 \\
\hline Pig & $25(41.7)$ & 2.6 & $4(6.7)$ & 1 & $29(24.2)$ & 2.4 \\
\hline Chicken & $52(35.7)$ & 8.6 & $54(90.0)$ & 7.4 & $106(88.3)$ & 7.9 \\
\hline
\end{tabular}

Source: Field Survey, 2008, Figures in parenthesis indicate percentage 
Cattles cannot graze on steep slopes, thus have to be fed by carrying loads of fodder from the forest. After goat, bullock is considered important for ploughing the fields. Bullocks are usually hired on the basis of labour exchange by other households who do not own bullocks. The cows reared in the Chepang area are usually small sized local breed, and are not very productive. Cows are thus reared for manure, rather than for milk. Buffalo is owned by very few households, as raising buffalo in such steep hills is very difficult. Buffaloes are harder to take care of, and are too heavy to be allowed out to pasture or to get water in the rugged terrain. He-buffaloes and she-buffaloes are often slaughtered during festivals; the meat and the price are shared equally by all the households, an extra share is given to the one who slaughters the animal. Chicken and pig are reared openly, and can be found running around the homesteads and even inside the house all the time. Chicken and pigs are mostly reared for own consumption, mostly slaughtered during festivals, and marriages; and are also sold sometimes. Many Chepangs rent in livestock from Bahuns, Chhetris, and Newars from the nearest road-head markets on adhiya basis. In this system, the Chepangs take all the responsibilities of rearing the livestock, in return of which they get half the share on the offsprings. So, if the goat gives birth to two kids, one of them will belong to the Chepang households, while another kid and the mother goat still belong to the non-Chepang owner. In the case of cows, the owners usually pay half the amount of the calf's worth to the Chepang household. Goat is the major livestock reared under the adhiya system. In this study, nearly $32 \%$ households in Shaktikhor and 40\% households in Handikhola rear goats under the adhiya system. Besides goat, few households also rear cows and pigs under this system.

\section{GATHERING WILD AND UNCULTIVATED FOOD PLANTS}

Wild and uncultivated plants collected from the forests, field bunds, and bushes nearby Bari and Khoriya are important source of food for the Chepangs. All the Chepang households covered by the study are involved in collection of such wild edibles. The study identified 55 wild edible plant species collected by the Chepangs. Out of them, 21 $(38.2 \%)$ are trees, $6(10.9 \%)$ are shrubs, $6(10.9 \%)$ are herbs, $12(21.9 \%)$ are vines, $7(12.8 \%)$ are mushrooms, $2(3.6 \%)$ are ferns, and $1(1.8 \%)$ 
is bamboo. The details of wild edible plants along with the parts used and food category are given in Annex 4. Food plants are categorized according to their indication for specific utility as vegetable, staple food, fruit, spice, pickle, oil, and liquor. It was found that the wild plants were mostly used as vegetables (22 plants), followed by fruit (18 plants), staple food (9 plants), spice (5 plants), pickle (4 plants), oil, and liquor (1 plant each). According to plant parts used, the wild species used as food by the Chepangs can be categorized into 11 types. It was found that the most frequently used plant part was fruit (25 plants), followed by young shoot (10 plants), tuber ( 9 plants), whole plant ( 7 plants), aerial yam, flower and leaf (3 plants each), seed (2 plants) and bark, stem, and rhizome (1 plant each).

In this study, 9 different wild tubers were identified, which form the major staple diet for the Chepangs during the lean periods after their agricultural harvest is depleted. The most commonly consumed tubers are gittha (Dioscorea bulbifera), bhyakur (Dioscorea pentaphylla), and tarul (Dioscorea alata). These tubers form the staple diet for most of the Chepang households from Falgun to Asadh (see Annex 3). Gittha-Bhyakur taste bitter when uncooked and the tubers are boiled in ash water to remove the bitterness. Ban tarul is the most delicious of all tubers, however its tubers are thin and long that extend deep into the soil because of which digging of tarul is more difficult. Bharlang, the most poisonous tuber, is a spiny shrub. Bharlang is consumed only when the household faces extreme food shortage. Uncooked Bharlang has a bitter smell, and causes headache, nausea, and vomiting if exposed for too long. Bharlang needs very careful precautions while preparing. The skin is first peeled, sliced and boiled in ash water for about an hour. The boiled slices are then soaked in running water in the river for about twenty-four hours. The next day, the slices are boiled seven times, changing the water each time, after which the tubers are rendered edible. If the poison remains, it causes nausea-vomiting, sometimes causing death by vomiting blood.

Besides these tubers, forest is the main source of green vegetables for this community. Sisnoo (Urtica dioica) is the most commonly consumed wild green vegetables, which can be consumed almost all the year round from Bhadra till Baisakh. It was found that Chepangs consumed the 
young shoot of tanki (Bauhinia purpurea) as green vegetables for eight month in a year from Falgun till Asoj (Annex 3). Other green vegetables commonly consumed include edible ferns (niuro), jaluko (Remusatia vivipora), and latte (Amaranthus spp). These green vegetables can also be collected from Falgun throughout the summer, sometimes till Asoj - Kartik. Wild green vegetables, especially sisnoo, tanki, and latte are very prolific in nature and can be found abundantly in the bushes nearby forests, and on the bunds of Bari and Khoriya. Young bamboo shoots are also commonly used as vegetables. These are collected during the summer months from Jestha till Bhadra and are sometimes stored by pickling to be used during the dry season as well. Chepangs also collect many wild varieties of mushrooms which sprout in the forest after the monsoon rains (from Asadh till Bhadra). The Chepangs claim to know the differences between poisonous and non-poisonous mushrooms, as well as prayers to cure illness if a mistake is made. The annual gathering calendar for the major wild vegetables is given in Annex 3 . Chiuri (Bassia butyracea), commonly known as butter tree for its rich oily seeds, is another important plant for the Chepangs in Shaktikhor. Chiuri trees are found abundantly in the forests around Shakikhor; few are also planted in Khoriyas. The pulp of Chiuri fruit often forms the major supplementary diet for the Chepangs from Jestha to Bhadra. The seeds are collected from the forests from Asadh till Asoj, and these are used to expel butter. Chiuri butter is the main source of cooking oil for the Chepangs. It is also used as hair oil, and as medicines for dry skin. Besides domestic uses, Chiuri butter also has commercial importance. It makes excellent raw materials for making quality soaps, and is bought by cosmetic companies. It is also used to light lamps in temples and monasteries in Kathmandu. Chepangs usually sell the Chiuri butter or seeds to the road-head traders during Asoj to make cash income for celebrating Dashain. In Shaktikhor, where Chiuri trees are in abundance, the Chepangs can identify 30 different varieties of Chiuri based on various biological features like flowering time, color, size, shape, texture, taste, smell, and productivity of leaf, plant, fruit, and seeds (Bhattarai et al., 2003). In Handikhola however, the trees of Bassia butyracea are not found because of lower elevations. It grows at an elevation of 700-1500 masl; whereas elevation of Handikhola is 350-700 masl. Thus, Bassia butyracea is not a part of the livelihood for 
the Chepang community there.

Many plants have multiple edible uses as well. For instance, young shoots and seeds of tanki and koiralo (Bauhinia variegata) are used as vegetables, and their flowers are used as pickles. The aerial yam of gittha, tarul, and kukkur tarul (Dioscorea deltoidea) is powdered and used as pickle. Wild varieties of timur (Xanthoxylum spp) and tejpaat (Cinnamomum tamala) are used as spices. Also, Chepangs consume fruits of many types of wild figs like dumri (Ficus racemosa), badahar (Artocarpus lakoocha), khanayo (Ficus semichordata), and pipal (Ficus religiosa). Wild fruits are often gathered and consumed when they visit the forest for grazing goats, and collecting fodders and firewood. However, these wild fruits are rarely brought home.

The amount of knowledge accumulated by Chepangs about food gathering is astounding. They collect, prepare and eat deadly poisonous roots. The Chepangs can distinguish the edible mushrooms from the poisonous ones. Chepangs can remove poison from poisonous tuber, bharlang, and from the seed of poisonous legume pangra (Entada phaseoloides) to render them edible. Except for Chiuri, edible wild plants used in the two study sites is almost the same.

\section{COMPLEMENTARITY BETWEEN FARMING AND GATHERING}

Although farming forms the mainstay of the Chepang livelihood, the rugged topography, steep slopes, stony lands, inadequate manure and irrigation facilities lead to a productive capacity too small to support the population. The average food self-sufficiency of the Chepang households covered by the study is around 7 months, and only $7.5 \%$ of the total households covered by the study are food self-sufficient. Similar findings were also reported by Aryal et al. (2009) and Bhattarai et al. (2003). Gurung (2006) and FORWARD (2001b) report even lower average food self-sufficiency of 5 months and that only $1 \%$ of total Chepang households is food self-sufficient. Gribnau et al. (1997) reports that only 4\% Chepang households were found to be selfsufficient. Gurung (2006) reports even lower figure of only 1 percent of total Chepang households being food self-sufficient. They face grain deficit from Falgun to Asar, the most chronic deficit being Chaitra to 
Jestha. The reason for food deficit during this period is because this is the dry season; the land basically remains fallow during the dry months due to lack of irrigation facilities. Also, due to infertile and stony nature of the land, crop productivity is low, and whatever is harvested earlier gets depleted by this time of the year while the new crop is not yet ready to be harvested.

Chepangs gather wild tubers as staple food during these grain-deficit months. As shown in Annex 3, the most commonly used tubers are gittha, bhyakur, and tarul, and these are collected during the months of Falgun to Jestha, the period exactly coinciding with the months reported to be the most grain-deficit. During these months, the little millet and other winter cereals harvested in Mangsir - Poush are already depleted, while the new crop of maize is not yet ready to be consumed. Thus Chepangs are compelled to depend on wild tubers during these months. Chiuri fruits that mature in Jestha - Asadh also form a major supplementary diet during these months.

Gathering complements not only the staple diet of the Chepangs, but also complements the green vegetables. As already stated, since Chepangs grow very few vegetables, they mostly depend on various kinds of wild and uncultivated green vegetables such as sisnoo, tanki, jaluko, niuro, and latte. During the dry months of Falgun to Jestha, there is shortage not only of grains, but also of green vegetables in the field of Chepangs (see Annex 2). Thus, during these months, the shortage of green vegetables is complemented from the wild sources. Wild green vegetables like sisnoo, tanki, jaluko, niuro, and latte can be gathered even during these dry months when there are no vegetables in the field. The vegetable deficit during winter months (Poush - Magh) is fulfilled by sisnoo, which can be gathered almost all the year round. Thus gathering complements not only the grain shortage, but also the vegetable shortage in the Chepang community. Thanks to these wild sources, green vegetables form a component of the Chepang diet all the year round (see also Bhattarai, 2004 and Gribnau et al, 1997). This complementary function of wild sources can be easily understood by comparing the cropping calendar in Annex 2 and gathering calendar in Annex 3. 
Annual subsisteence...... Piya, Maharian, Joshi

Chiuri seed is another important component of wild edibles collected by the Chepangs in Shaktikhor. Butter is extracted from these seeds during Bhadra - Kartik, and is used as cooking oil, which is barely sufficient until the little amount of mustard that is grown by very few households is harvested in Magh - Falgun. Once the stock of Chiuri butter and mustard oil is over, vegetables are simply boiled in saltwater and eaten. Chepangs buy oil from the market only during festivals when they have to cook meat.

Wild and uncultivated foods are important not only from the aspect of food security, but also from the aspects of food diversity and they undoubtedly contribute to the nutritional requirements for the Chepang community. A study showd that gittha and bhyakur, the major wild tuber consumed by Chepangs, contain five times more protein and fiber than potato and sweet potato (Bhandari, 1995). The study further showed that important elements like iron, calcium, and phosphorous are also available in these wild foods. Many wild foods consumed by Chepangs also perform dual role of food as well as medicine. For instance, Chiuri butter also has medicinal values for treating rheumatism, wounds, and dry skin.

\section{CONCLUSION AND RECOMMENDATIONS}

The Chepang subsistence agriculture economy lies between scarcity and bare sufficiency. Rugged topography, stone lands, limited manures, and lack of irrigation facilities lead to lower productivity of the crops cultivated. Maize and millet are the two most important staple crops cultivated by the Chepangs. However, millet has received very little attention in the mainstream researches. Varietal improvement of millet to increase the yield even under limited fertilizer and water input would contribute to the food self-sufficiency of the Chepangs. The wild and uncultivated plant species strongly contribute to the subsistence livelihoods of the Chepangs. Wild tubers complement the grain-deficit during the dry periods when the stored food supply is dwindling and the new harvests are not yet obtained. Besides staple foods, wild sources also contributed to the supply of green vegetables for the Chepang community. Chepangs cultivate very limited green vegetables, and rather rely on wild sources such as sisnoo, tanki, latte, 
jaluko, and niuro which are hardier, and regenerate easily throughout the year, even during the dry seasons. Conservation and sustainable use of uncultivated foods have, however, received relatively little attention in development activities. Development agencies working with this community have put their effort only in promoting hybrid varieties of vegetables which are more prone to pest and disease infestation, and do not give optimum yield in the absence of adequate inputs like chemical fertilizers, pesticides, and water. Chepangs on the other hand are not in a position to supply all the necessary inputs, as a result of which the hybrid vegetables are, on the one hand, giving lesser production, while on the other hand displacing the more resistant local varieties, especially in the case of gourds and cucumber. Little emphasis has been made for the promotion of uncultivated species that are of importance to the Chepangs. Uncultivated plants remain important resources, therefore, updated inventories and information of these resources in terms of availability and use is essential. Some of these wild plants might have the potential to become valuable staple crops and important alternatives to the usual food crops cultivated by the Chepangs. There is a need to undertake action research based projects in order to exploit the potential of these wild foods and examine the possibilities of domestication. Without the understanding of the importance of both staple crop foods and uncultivated foods, agricultural planning will continue to focus on a few major crops and exclude the diverse and important uncultivated food resources. For Chepang people, who are subsisting their livelihoods by the combination of farming and gathering wild foods, losing one of the key components of their food i.e. wild edible plants would mean a major threat to their food security. It is thus important to understand how staple food crops and wild uncultivated food crops complement each other so as to maximize the food security of the Chepang community. This paper has its limitations in that it does not explore the dependence of Chepang community on hunting and fishing. Future studies focusing on the contribution of wild fauna to the subsistence livelihoods of these people is highly recommended.

\section{END NOTES}

${ }^{1}$ According to National Foundation for Development of Indigenous Nationalities Act 2002, indigenous nationalities means tribes or 
communities having their own mother language and traditional rites and customs, distinct cultural identity, distinct social structure and written or unwritten history. Based on the same Act, Nepal Government has identified 59 Indigenous Nationalities (NIRS, 2006).

2 The 59 indigenous nationalities in Nepal are classified into five groups comprising of endangered, highly marginalized, marginalized, disadvantaged, and advanced group. This classification is based on a composite index comprising of variables like literacy rate, housing, land holdings, occupation, language, graduates, residence, and population size. The indigenous nationalities are further classified into mountains, hills and tarai based on the geographical location where they form a majority. Chepangs fall under hilly and highly marginalized indigenous nationalities, together with Baramu, and Thami.

${ }^{3}$ Makai means maize and bodi means cowpea; makai bodi is a variety of cowpea that is mixed cropped together with maize.

${ }^{4}$ This variety of cowpea is ready to be consumed during the month of Kartik.

${ }^{5}$ Dheeka means lumps and noon means salt in Nepali; referring to the unprocessed salt in crystal form.

\section{REFERENCES}

Aryal, K.P., A. Berg, and B. Ogle. (2009). "Uncultivated Plants and Livelihood Support - A Case Study from the Chepang People of Nepal" in Ethnobotany Research and Applications, Vol. 7, pp. $409-422$.

Bastakoti, R., and K. Kattel. (2008). "Agro-biodiversity Conservation Programme in the Chepang Community: Some Achievement, Some Challenges", in R. Bastakoti and L. Sharma (eds.). Chepang Food Culture and Agrobiodiversity (In Nepali). Resource Identification and Management Society Nepal, pp. 48 - 56.

Bhandari, M.R. (1995). Study on Food Value, Nutritional and Biochemical Characteristics of Lesser Known Wild Yam (Dioscorea spp) Tubers of Nepal. Hokkaido: Graduate School of Agriculture, Hokkaido University. 
Bhattarai, T.K. (ed.) (1999). Chepangs: Awareness and Identity, Report of the Second Gathering of the Chepangs and the Concerned (In Nepali). School of Ecology, Agriculture, and Community Works, Kathmandu, Nepal.

(2004). Development and Economical Politics of Indigenous People (In Nepali). Kathmandu: School of Ecology, Agriculture and Community Works, Centre for AgroEcology and Development.

Bhattarai, T.R., P. Dahal, N.B. Chepang, K. BK, K. Chepang, J. Chitrakar, G. Ghimire, D. Adhikari, B. Subba, and B.B. Chepang. (2003). "Learning to Manage and Market Chiuri Products in Central Nepal", in P. Van Mela (ed.) Way out of the woods: Learning How to Manage Trees and Forests. Newbury, UK: CPL Press.

CBS. (2003). Population Monograph of Nepal, Volume I. Kathmandu: National Planning Commission Secretariat, Central Bureau of Statistics.

(2006). Monogaph: Agriculture Census Nepal, 2001/02. Kathmandu: National Planning Commission Secretariat, Central Bureau of Statistics.

(2008). National Population Census, 2001 (castelethnicity population) (In Nepali). National Planning Commission Secretariat, Central Bureau of Statistics, Kathmandu, Nepal.

FORWARD. (2001a). Formulation of a Comprehensive Praja Development Programme, Part I, A Synthesis of Database. Prepared for Ministry of Local Development, Kathmandu, and SNV-Nepal. Forum for Rural Welfare and Agricultural Reform for Development, Chitwan, Nepal.

(2001b). Formulation of a Comprehensive Praja Development Programme, Part II, Program Development. Prepared for Ministry of Local Development, Kathmandu, and SNV-Nepal. Forum for Rural Welfare and Agricultural 
Annual subsisteence...... Piya, Maharjan, Joshi

Reform for Development, Chitwan, Nepal.

Gribnau, C., S. Pradhan, S. Rana, N.S. Chhetri, S. Ghimire. (1997). Can Orange Tree Blossom on a Barren Land: Identification of Development Potentials of Praja Communities in Chitwan District (In Nepali). Praja Community Development Programme, Chitwan, Nepal.

Gurung, B. (2006). "Chepang Mainstreaming Programme: A Brief Introduction". Voice of Chepang, A Monthly Newsletter in Nepali Language, March, 2006. Kathmandu, Nepal: Nepal Chepang Association. pp: 4-10.

Gurung, G.M. (1994a). "Modernization of Economy in a Chepang Village of Nepal" in The Chepangs: A Study in Continuity and Change. S. Gurung, Kathmandu, Nepal, pp. 57-68.

(1994b). "A Note on the Religious Beliefs and Practices among the Chepangs of Nepal" in The Chepangs: A Study in Continuity and Change. Kathmandu, S. Gurung, Kathmandu, Nepal, pp. 69-84.

(1995). Report from A Chepang Village: Society, Culture, and Ecology. Kathmandu, S. Gurung, Kathmandu, Nepal.

Hodgson, B. H. (1874). "On the Chepang and Kusunda Tribe of Nepal" in Essays on the Languages, Literature and Religion of Nepal and Tibet, New Delhi: Manjushri Publishing House, pp. 45-54.

Neis, L. (1989), Soon this Voice will be Lost and Gone: Stories from a Chepang Village, Wisconsin-Madison: University of Wisconsin-Madison, USA.

NGIIP. (2006). Index of Geographical Names of Nepal, Central Development Region, Volume II. National Geographic Information Infrastructure Programme, Survey Department, Government of Nepal, Kathmandu, Nepal. http://www.ngiip.gov.np/publications/volume2link.php [Retrieved January $9^{\text {th }} 2011$ ]. 
NIRS. (2006). Socio-Economic Status of Indigenous Peoples (Based on Nepal Living Standards Survey - 2003/04 data set). Kathmandu: Nepal Integrated Research System Pvt. Ltd.

Piya, L., K. L. Maharjan, and N. P. Joshi. (2011a). "Forest and Food Security of Indigenous People: A Case of Chepangs in Nepal", in Journal of International Development and Cooperation, Vol. 17, No. 1 (forthcoming).

(2011b). "Livelihood Strategies of Indigenous Nationalities in Nepal: A Case of Chepangs" in Journal of International Development and Cooperation, Vol. 17, No. 2 (forthcoming).

Rai, N.K. (1985). People of the Stones: The Chepangs of Central Nepal. Kathmandu: Centre for Nepal and Asian Studies, Tribhuvan University, Kirtipur.

Riboli, D. (2000). Tunsuriban: Shamanism in the Chepang of Southern and Central Nepal. Kathmandu: Mandala Book Point.

SNV, (2008). Let the People Lead: Lessons for Working Effectively with Excluded Groups: The Chepang Community's Experience in Nepal. Kathmandu: Netherlands Development Organization (SNV).

Upreti, B. R. and J. Adhikari. (2006). A Case Study on Marginalized Indigenous Communities' Access to Natural Resources in Nepal: National Laws, Policies, and Practices. Preliminary Draft Presented at the National Thematic Dialogue Held on 17 February 2006 and 19 February 2006, Kathmandu, Nepal.

Annex 1. Conversion Table for Nepali Months to English Months

\begin{tabular}{|l|l|l|l|}
\hline Nepali months & \multicolumn{1}{|c|}{ English months } & Nepali months & \multicolumn{1}{c|}{ English months } \\
\hline 1. Baisakh & Mid April to Mid May & 7. Kartik & Mid October to Mid November \\
\hline 2. Jestha & Mid May to Mid June & 8. Mangsir & Mid November to Mid December \\
\hline 3. Asadh & Mid June to Mid July & 9. Poush & Mid December to Mid January \\
\hline 4. Shrawan & Mid July to Mid August & 10. Magh & Mid January to Mid February \\
\hline 5. Bhadra & Mid August to Mid September & 11. Falgun & Mid February to Mid March \\
\hline 6. Ashwin & $\begin{array}{l}\text { Mid September to Mid } \\
\text { October }\end{array}$ & 12. Chaitra \\
\hline
\end{tabular}


Annex 2. Annual Crop Calendar

\begin{tabular}{|c|c|c|c|c|c|c|c|c|c|c|c|c|}
\hline Crop & Baisakh & Jestha & Asadh & Shrawan & Bhadra & Asoj & Kartik & Mangsir & Poush & Magh & Falgun & Chaitra \\
\hline \multicolumn{13}{|c|}{ Cereals, Legumes, and Oilseed } \\
\hline Maize & $\mathbf{P}$ & & $\mathbf{H}$ & $\mathbf{H}$ & H & & & & & & P & P \\
\hline Millet & & & & P & P & & $\mathbf{H}$ & $\mathbf{H}$ & H & & & \\
\hline Buckwheat & & & & & & $\mathbf{P}$ & $\mathrm{P}$ & & $\mathbf{H}$ & H & & \\
\hline Wheat & & & & & & & $\mathrm{P}$ & $\mathrm{P}$ & & & H & $\mathbf{H}$ \\
\hline Paddy & & & $\mathrm{P}$ & P & & & H & H & & & & \\
\hline Soybean & & & $\sqrt{10}$ & $\mathrm{P}$ & & & & $\mathbf{H}$ & H & & & \\
\hline Blackgram & & & $\mathbf{P}^{\mathrm{P}} \mathbf{3}$ & $\mathbf{P}^{\mathrm{P}}$ & & & & H & $\mathrm{H}$ & & & \\
\hline Cowpea (Makai) & P & H & $\mathbf{H}$ & $\mathbf{H}$ & H & & & & & & I & P \\
\hline $\begin{array}{l}\text { Cowpea } \\
\text { (Kattike) }\end{array}$ & & & & P & P & $\mathbf{H}$ & H & $\mathbf{H}$ & & & & \\
\hline Masyang & & & & $\frac{P}{P}$ & P & & & $\mathbf{H}$ & $\mathbf{H}$ & & & \\
\hline Horsegram & & & & $\sqrt{3}$ & $\mathrm{P}$ & & & H & H & & & \\
\hline Mustard & & & & & P & $\mathbf{P}$ & & & & H & H & \\
\hline \multicolumn{13}{|c|}{ Spice and Vegetables } \\
\hline \multirow[t]{2}{*}{ Chilly } & \multicolumn{4}{|c|}{ 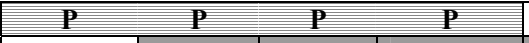 } & & & & & & & & $\mathrm{P}$ \\
\hline & & $\mathbf{H}$ & H & H & $\mathrm{H}$ & $\mathbf{H}$ & $\mathbf{H}$ & $\mathbf{H}$ & $\mathbf{H}$ & & & \\
\hline \multirow{2}{*}{$\begin{array}{ll}\text { Broad } & \text { leaved } \\
\text { mustard } & \\
\end{array}$} & & & & $\mathbf{P}$ & P & Pla & & & & & & \\
\hline & & & & & & $\mathbf{H}$ & $\mathbf{H}$ & $\mathbf{H}$ & $\mathbf{H}$ & $\mathbf{H}$ & & \\
\hline \multirow[t]{2}{*}{ Radish } & & & & P & P & P & $\mathrm{P}$ & & & & & \\
\hline & & & & & & H & H & H & H & & & \\
\hline Pumpkin fruit & P & P & $\mathrm{H}$ & $\mathrm{H}$ & $\mathrm{H}$ & $\mathbf{H}$ & & & & & 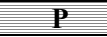 & P: \\
\hline \multirow[t]{2}{*}{ Pumpkin shoot } & $\mathbf{P}$ & $4 \mathrm{P}$ & & & & & & & & & 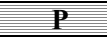 & 13 \\
\hline & H & $\mathbf{H}$ & $\mathbf{H}$ & $\mathbf{H}$ & $\mathbf{H}$ & & & & & & & H \\
\hline Gourds & P & $\mathrm{H}$ & $\mathbf{H}$ & $\mathbf{H}$ & $\mathrm{H}$ & $\mathrm{H}$ & & & & & $\mathrm{P}$ & $\mathrm{P}$ \\
\hline Cucumber & & & H & H & H & & & & & & $\mathbf{P}$ & Pie \\
\hline Chayote & & & & & & H & H & H & H & & 踥 & P \\
\hline Colocasia leaf & & & & $\mathbf{H}$ & $\mathbf{H}$ & & & & & & P & P \\
\hline Colocasia tuber & & & & & & & & H & $\mathbf{H}$ & H & $\mathbf{P}$ & 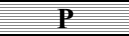 \\
\hline
\end{tabular}



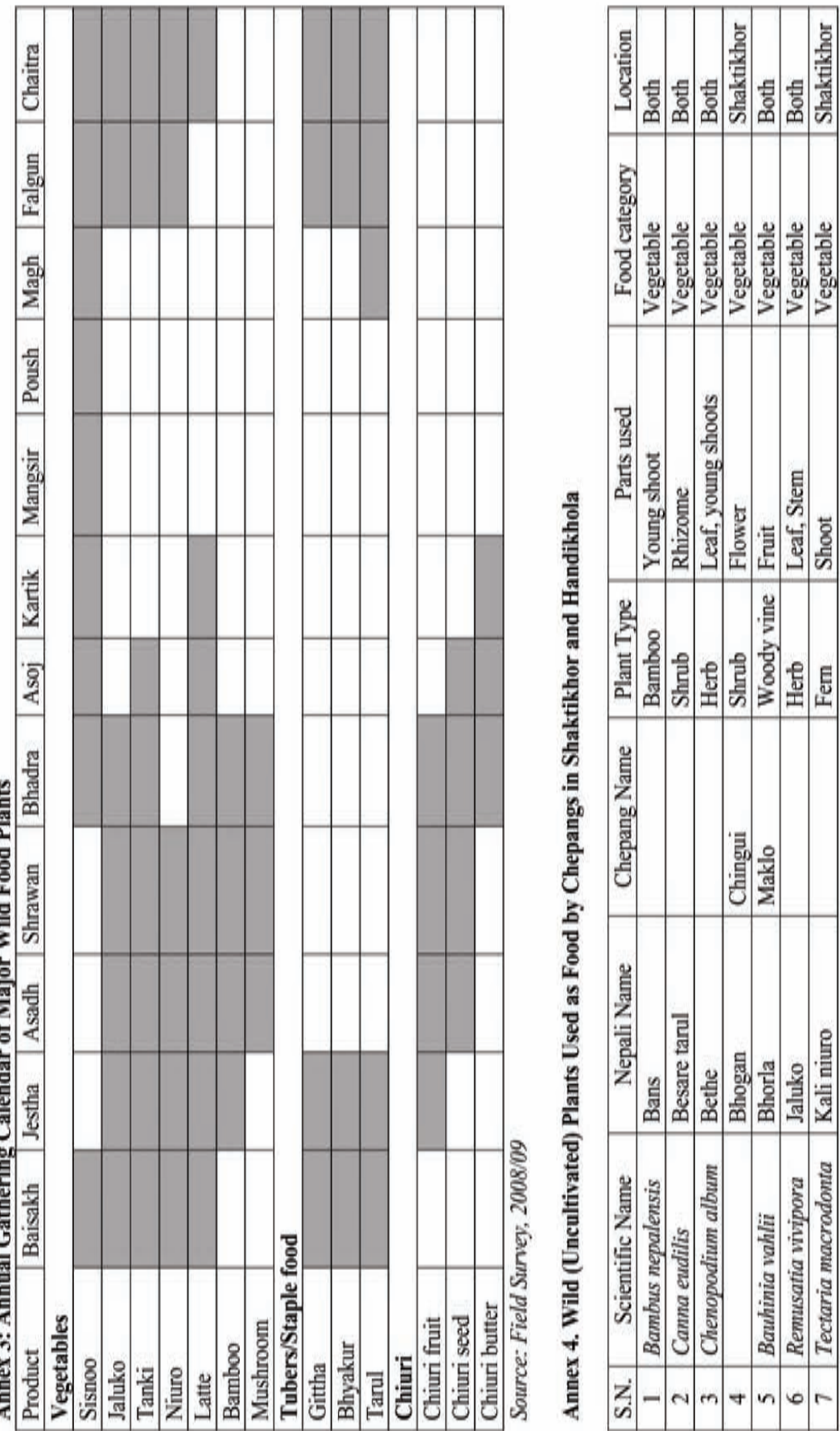
Annual subsisteence...... Piya, Maharjan, Joshi

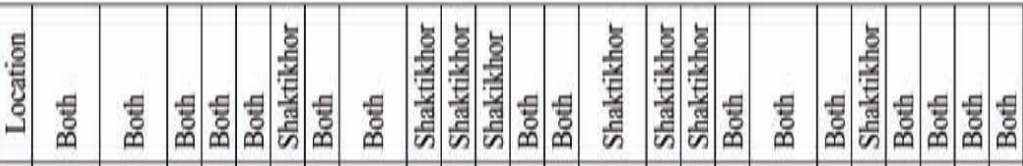

는

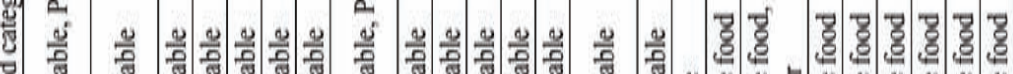

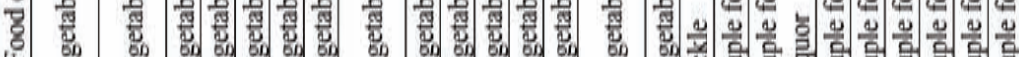

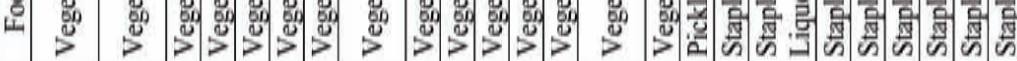

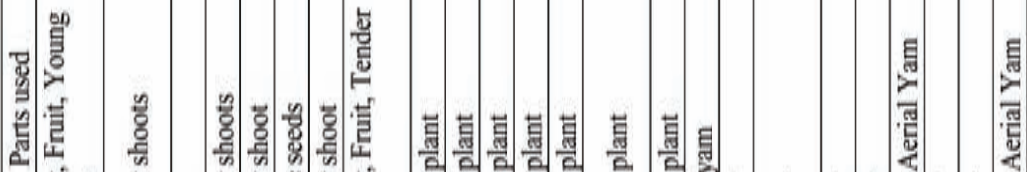

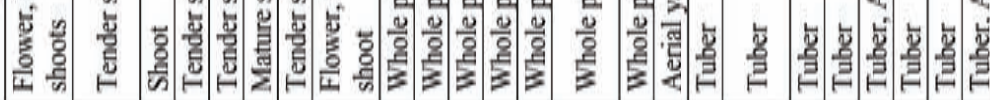

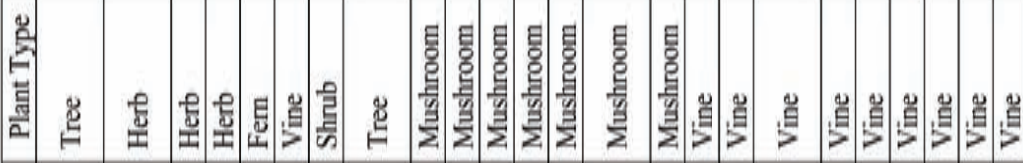

党

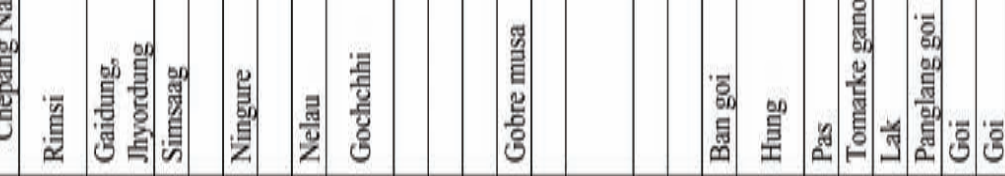

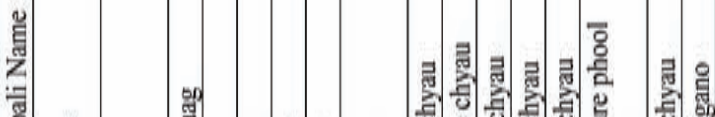

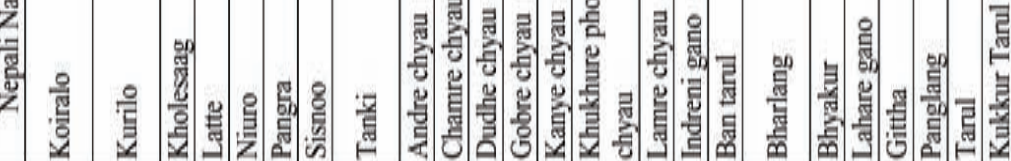

\begin{tabular}{|c|c|c|c|c|c|c|c|c|c|c|c|c|c|c|c|c|c|c|c|c|c|}
\hline & & & 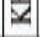 & 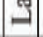 & $z$ & 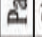 & $\bar{n}$ & $\mapsto$ & $\angle 0$ & 3) & 5 & 9 & 들 & $\exists$ & 罗 & 䓃 & 3 & 30 & a. & $\stackrel{H}{H}$ & $\$$ \\
\hline 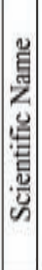 & है: & $\begin{array}{l}\text { है } \\
\text { है } \\
\text { है } \\
\text { है }\end{array}$ & 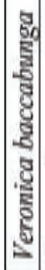 & 告 & 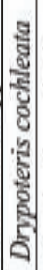 & 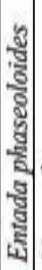 & $\begin{array}{l}3 \\
5 \\
5 \\
5 \\
5 \\
5 \\
5 \\
5\end{array}$ & 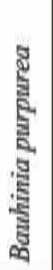 & & & 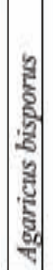 & & & & 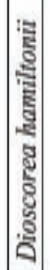 & 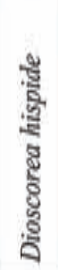 & 产 & 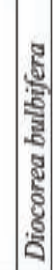 & 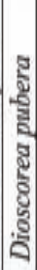 & 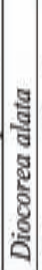 & . \\
\hline & $\infty$ & $\phi$ & 을 & $=$ & 웍 & 2 & \pm & 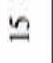 & 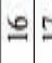 & $=\infty$ & 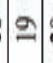 & 8 & $\vec{\theta}$ & Aत् & तs & 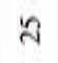 & ती & $=0$ & & 유 & 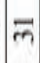 \\
\hline
\end{tabular}


Himalayan Journal of Sociology \& Antropology-Vol. IV (2010)

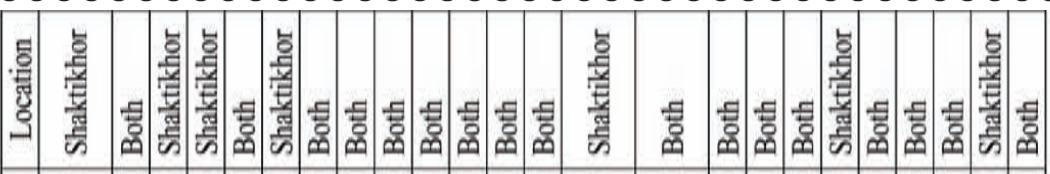

t:

范

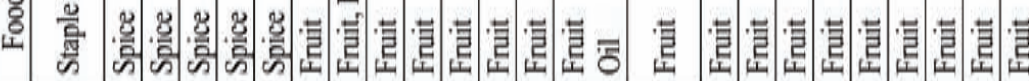

作

密

:

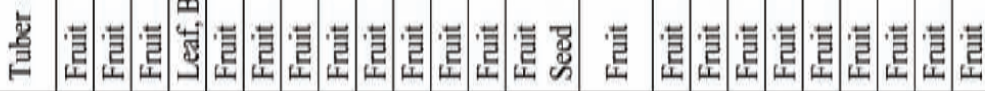

象

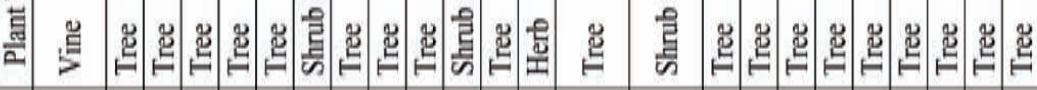

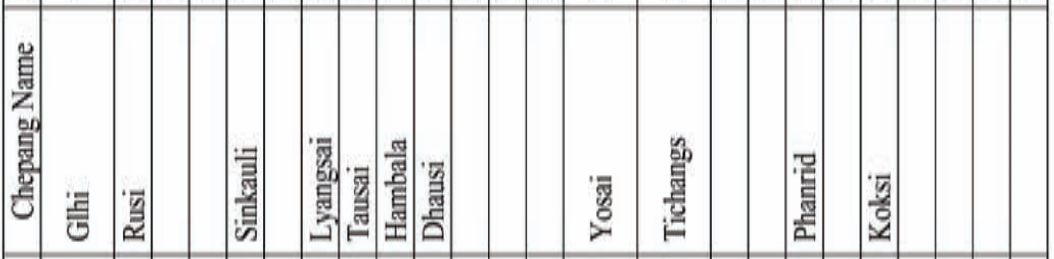

善

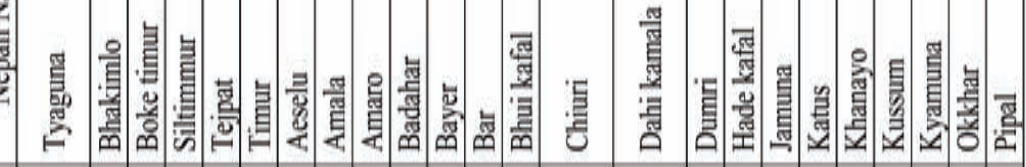

을

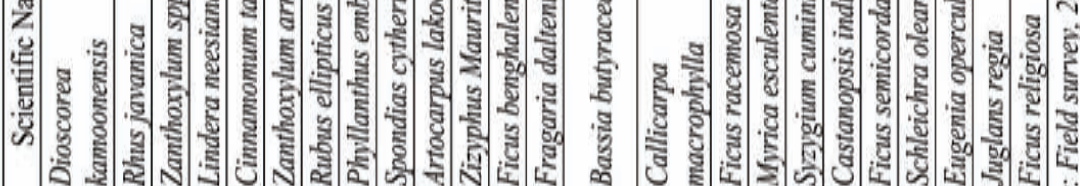

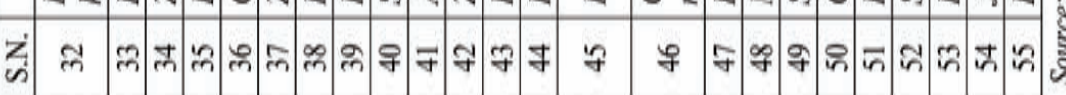

